\title{
PERAN PONDOK PESANTREN \\ DALAM MEMBINA KEBERAGAMAAN SANTRI
}

\author{
M. Faisol \\ emfadamai212@gmail.com \\ Universitas Nurul Jadid
}

\begin{abstract}
Abstrak: Penelitian ini berupaya menggali lebih dalam tentang relasi masyarakat dengan pondok pesantren dan peran pondok pesantren dalam pembinaan keberagamaan santri. Pertanyaan utama yang ingin dijawab melalui penelitian ini adalah bagaimana perilaku keberagamaan santri dan bagaimana peran pondok pesantren dalam meningkatkan perilaku keberagamaan santri. Metode yang penulis gunakan dalam penelitian ini adalah penelitian kualitatif. Penelitian ini dilakukan mulai bulan November 2017 di pondok pesantren Nurul Jadid melalui observasi dan pengamatan langsung. Temuan dalam penelitian ini diharapkan menjadi sumbangan pengetahuan dan menjadi rujukan bagi penelitipeneliti selanjutnya untuk lebih disempurnakan lagi.
\end{abstract}

\section{Kata Kunci: Pesantren, Pembinaan, Santri, Keberagamaan}

\section{A. Pendahuluan}

Pesantren sejak awal tumbuh dan berkembang di berbagai daerah di Indonesia, telah dikenal sebagai lembaga keislaman yang mempunyai nilainilai strategis dalam pengembangan masyarakat Indonesia. Sejak kemunculannya ratusan tahun yang lalu, pesantren telah menjangkau berbagai lapisan masyarakat khususnya masyarakat muslim. Keberadaan pesantren telah diakui banyak kalangan sebagai lembaga pendidikan yang turut serta mencerdaskan kehidupan bangsa.

Mengingat pentingnya pendidikan dalam upaya mengangkat harkat dan martabat serta menyiapkan manusia yang memiliki intelektualitas, spiritualitas dan akhlakul karimah, maka pendidikan semacam ini memerlukan suatu usaha dan pemikiran yang keras dan serius dalam upaya mewujudkan cita-citanya (Baharun, 2016b).

Pondok pesantren mempunyai berbagai peran penting dalam meningkatkan kualitas sumber daya manusia (Baharun, 2017). Seperti pada umumnya telah diketahui bahwa pesantren sebenarnya tidak hanya 
memberikan pengetahuan dan keterampilan teknis, tetapi yang jauh lebih penting adalah menanamkan nilai-nilai moral dan agama. Filosofi pendidikan pesantren didasarkan atas hubungan yang berarti antara manusia dengan Allah SWT. Hubungan tersebut mempunyai arti jika bermuatan atau menghasilkan keindahan dan keagungan. Ibadah yang dijalani oleh semua guru dan santri di pondok pesantren diutamakan dalam hal menuntut ilmu, mengelola pelajaran, mengembangkan kemampuan diri, mengembangkan kegiatan bersama santri dan masyarakat. ${ }^{1}$

Glock dan Stark mengatakan bahwa perilaku keberagamaan manusia dapat dilihat dari lima dimensi utama, yaitu: ideological, ritual, mistikal, intelektual, dan sosial. ${ }^{2}$ Sedangkan menurut Zakiah Daradjat, agama seseorang ditentukan oleh pendidikannya, pengalaman dan pelatihanpelatihan yang dijalani pada masa kecilnya dulu, seorang yang pada masa kecilnya tidak pernah mendapatkan pendidikan agama maka pada saat dewasa kelak, ia kurang merasakan pentingnya akan agama dalam hidupnya, terutama pada anak usia remaja. ${ }^{3}$

Seperti halnya dengan sebuah aliran empirisme yang dicetuskan oleh John Locke sebagaimana dikutip oleh Lilik Sriyanti yang mana aliran ini memandang bahwa perkembangan manusia ditentukan oleh pengalaman dari lingkungannya. ${ }^{4}$ Umpamanya seseorang yang berada pada lingkungan yang baik akan tumbuh menjadi pribadi yang baik pula. Pondok Pesantren Nurul Jadid merupakan salah satu solusi penting bagi orang tua yang mempunyai anak usia remaja dan ingin mengenalkan lebih jauh tentang ilmu-ilmu agama kepada putra-putrinya. Hubungan antara warga pesantren di satu pihak dan masyarakat di lain pihak meliputi berbagai aspek kehidupan, salah satunya adalah pendidikan. Pihak warga pesantren terutama para kyai dan dewan guru berperan sebagai pemberi informasi (komunikator), baik yang berwatak

${ }^{1}$ Nafi', M. D., dkk., Praksis Pembelajaran Pesantren, 2007, Yogyakarta: Institute for Training and Development Amherst MA. Hlm, 9.

2 Charles Y. Glock and Rodney Stark Religion and Society in Tension, 1965, Chicago: Rand McNally and Company. Hlm, 306.

3 Zakiyah Darajad, Ilmu Jiwa Agama, 1996, Jakarta: PT. Bulan Bintang. Hlm, 35.

4 Lilik Sriyanti, dkk., Teori-Teori Belajar, 2011, Salatiga: STAIN Salatiga. Hlm, 19. 
agama (melalui pesantren), maupun ilmu pengetahuan umum melalui lembaga-lembaga pendidikan formal yang ada di lingkungan pesantren tersebut. Sedangkan warga masyarakat khususnya remaja usia sekolah berperan sebagai penerima informasi. ${ }^{5}$

\section{B. Metode Penelitian}

Penelitian kualitatif adalah penelitian yang berusaha menemukan makna dari sebuah situasi atau kondisi. Metode penelitian ini berlandaskan pada filsafat postpositivisme yang memandang realitas sosial sebagai suatu yang utuh, komplek, dinamis dan penuh makna serta bersifat interaktif dan hasil penelitiannya lebih menekankan makna daripada generalisasi. ${ }^{6}$ Dalam penelitian ini peneliti mencoba mencari tahu bagaimana sikap keberagamaan santri pada lingkungan pondok pesantren. Penelitian ini menggunakan pendekatan lapangan (field research), dimaksudkan untuk mengetahui data responden secara langsung di lapangan, yakni suatu penelitian tentang studi yang mendalam mengenai suatu unit sosial sedemikian rupa sehingga menghasilkan gambaran yang terorganisir dengan baik mengenai unit sosial tersebut. Adapun metode penelitian yang digunakan adalah kualitatif.

Penelitian ini di lakukan di pondok pesantren Nurul Jadid, Dusun Tanjung, Desa Karanganyar, Kecamatan Paiton, Kabupaten Probolinggo. Sedangkan yang menjadi objek penelitian ini adalah Pondok Pesantren Nurul Jadid. Subyek penelitian adalah orang dari lokasi penelitian yang dianggap paling mengetahui masalah penelitian guna memperoleh data-data penelitian. Informan adalah orang dari lokasi penelitian yang paling mengetahui permasalahan dan bersedia dijadikan sumber informasi, bersedia bekerja sama, mau diajak diskusi membahas hasil penelitian. ${ }^{7}$ Dalam penelitian ini yang menjadi subyek penelitian adalah Pondok Pesantren Nurul Jadid, Dusun Tanjung, Desa Karanganyar, Kecamatan Paiton, Kabupaten Probolinggo.

\footnotetext{
66.

${ }^{6}$ Sugiyono, Metode Penelitian Kuantitatif dan Kualitatif dan RED, 2011, Bandung: Alfabeta. Hlm, 8 .

${ }^{7}$ Moh. Kasiram, Metodologi Penelitian Kualitatif-Kuantitatif, 2010, Yogyakarta: UIN-Maliki Press. Hlm, 283.
}

${ }^{5}$ Sindu Galba, Pesantren Sebagai Wadah Komunikasi, 1995, Jakarta: PT Rineka Cipta. Hlm, 65- 
Fungsi dari subyek penelitian dan informan adalah membantu peneliti dalam waktu yang relatif singkat dapat memperoleh data yang banyak dan yang dibutuhkan selama penelitian berlangsung. Cara yang digunakan untuk mendapatkan informasi dari informan yang dapat dipertanggung jawabkan, dapat melalui wawancara. Untuk mendapatkan informasi yang dibutuhkan maka peneliti berpedoman pada informasi yang diberikan oleh pengurus pondok pesantren Nurul Jadid, para santri, dan santri sebagai informan. Prosedur pengumpulan data yang digunakan oleh peneliti dalam mencari data dan informasi penelitian adalah dengan menggunakan metode wawancara, observasi, dan dokumentasi. Wawancara merupakan pertemuan dua orang untuk bertukar informasi dan ide melalui Tanya jawab, sehingga dapat dikonstruksikan makna dalam suatu topik tertentu. ${ }^{8}$ Dalam hal ini penulis berpedoman pada informasi yang diberikan oleh pengurus pondok pesantren.

Secara umum, observasi berarti pengamatan, penglihatan. Sedangkan secara khusus, dalam dunia penelitian, observasi adalah mendengar dalam rangka memahami, mencari jawab, mencari bukti terhadap fenomena social keagamaan (perilaku, kejadian-kejadian, keadaan, benda, dan symbol-simbol tertentu) selama beberapa waktu tanpa mempengaruhi fenomena yang di observasi, dengan mencatat, merekam, mempotret fenomena tersebut guna penemuan data analisis. ${ }^{9}$ Metode observasi dalam penelitian ini dimanfaatkan untuk mengamati kondisi santri Nurul Jadid yang diharapkan dapat membantu untuk melengkapi data yang diperlukan dengan cara mengamati aktivitas kehidupan sehari-hari santri tersebut.

Dokumen merupakan metode penelitian yang berbentuk tulisan, gambar, atau karya-karya monumental dari seseorang. ${ }^{10}$ Peneliti menggunakan metode ini untuk mendapat data tentang kondisi dan keadaan Nurul Jadid, agamanya, dan sarana prasarana yang dimiliki dalam kegiatan

8 Sugiyono, Metode Penelitian ....... Hlm, 231.

${ }^{9}$ Imam Suprayogo dan Tobroni, Metodologi Penelitian Sosial Agama, 2001, Bandung: PT Santri Rosdakarya. Hlm, 167.

10 Sugiyono, Metode Penelitian ...... Hlm, 240. 
keagamaan. Tahap analisis data dalam penelitian ini secara umum dimulai sejak pengumpulan data, reduksi data, penyajian data, dan penarikan kesimpulan atau verifikasi. Reduksi data merupakan proses pemilihan, pemusatan perhatian pada penyederhanaan, pengabstrakan, transformasi data kasar yang muncul dari catatan-catatan lapangan. ${ }^{11}$ Pada proses ini peneliti dapat melakukan penggolongan, dan membuang yang tidak diperlukan. Setelah datanya terpilih maka dilakukan penyajian data yang didapat melalui informan dan data yang diperoleh dilapangan selama penelitian berlangsung. Penyajian data adalah menyajikan sekumpulan informasi yang tersusun yang memberi kemungkinan adanya penarikan kesimpulan dan pengambilan tindakan. Sehingga setelah penyajian data dapat ditarik kesimpulan sebagai hasil akhir penelitian.

Dalam melakukan pengecekan keabsahan data didasarkan pada beberapa kriteria. Kriteria tersebut terdiri dari credibility (derajat kepercayaan), transferability (validitas eksternal), dependability (reliabilitas) dan confirmability (obyektivitas). Masing-masing teknik tersebut menggunakan cara pemeriksaan sendiri-sendiri. Untuk kriteria derajat kepercayaan dalam memeriksa data maka peneliti memperpanjang keikutsertaannya, ketekunan dalam mengamati segala sesuatu objek di lapangan, triangulasi (teknik pengumpulan data yang bersifat menggabungkan dari berbagai teknik pengumpulan data dan sumber data yang telah ada), diskusi dengan teman sejawat, analisis kasus negatif dan member-check atau pengecekan data yang diperoleh peneliti kepada pemberi data. ${ }^{12}$ Tahap-tahap yang dimaksudkan dalam penelitian kualitatif di bagi ke dalam tiga tahap, yaitu: tahap pralapangan, tahap pekerjaan lapangan, dan tahap analisis data. ${ }^{13}$ Dengan demikian dapat dikatakan bahwa tahapan dalam penelitian ini adalah bentuk urutan atau berjenjang yaitu dimulai dari tahap pra-penelitian, tahap pekerjaan lapangan, dan tahap pasca penelitian. Namun walau demikian, sifat

${ }^{11}$ Imam Suprayogo dan Tobroni, Metodologi ...... Hlm, 92-193.

12 Sugiyono, Metode Penelitian ...... Hlm, 270.

${ }^{13}$ Lexy J. Moleong, Metodologi Penelitian Kualitatif, 2009, Bandung: PT Santri Rosda Karya. Hlm, 127-148. 
dari kegiatan yang dilakukan pada masing-masing tahap tersebut tidaklah bersifat ketat, melainkan sesuai dengan situasi dan kondisi yang ada.

\section{Pondok Pesantren Nurul Jadid}

Pesantren berasal dari kata santri, yang berarti tempat tinggal para santri, Profesor Jhons berpendapat bahwa istilah santri berasal dari bahasa Tamil yang berarti guru mengaji, sedangkan C.C. Berg berpendapat bahwa istilah tersebut berasal dari istilah shastri yang dalam bahasa India berarti orang yang tau buku-buku suci agama Hindu, atau seorang sarjana ahli kitab suci agama Hindu. ${ }^{14}$

Sedangkan pondok pesantren menurut Nurcholis Majid adalah tempat berkumpulnya para santri atau asrama tempat mengkaji ilmu agama Islam, di mana santri mempunyai image sebagai seorang yang mengerti lebih jauh mengenai perihal agama di banding masyarakat umum. Pesantren adalah lembaga pendidikan keagamaaan yang mempunyai ciri khasnya sendiri dibanding dengan lembaga pendidikan lainnya. Sebagai lembaga pendidikan yang sudah lama berkembang di Indonesia, pesantren berhasil membina dan mengembangkan kehidupan beragama masyarakat. Pondok pesantren merupakan sarana untuk menyiapkan para santri sebagai mutafaqqih fi al-din (mengkaji ilmu agama) yang mampu mencetak kader-kader ulama' dan pendakwah menyebarkan agama Islam, serta pembentukan akhlak. ${ }^{15}$ Selain itu, pondok pesantren juga dimanfaatkan masyarakat sebagai sarana mengembangkan kepercayaaan Islam, dan utamanya untuk mengembangkan kemampuan menafsirkan inti ajaran Islam. Sebuah pondok pesantren biasanya mempunyai elemen-elemen yang mendukung eksistensinya. Elemen-elemen pondok pesantren setidaknya terdiri atas pondok atau asrama untuk santri, masjid, pengajaran kitab-kitab klasik, santri, dan kyai. ${ }^{16}$

Masyarakat dan pemerintah mengharapkan pondok pesantren mempunyai peranan yang besar terhadap pendidikan Islam di Indonesia, di

14 Zamakhsyari Dhofier, Tradisi Pesantren: Studi tentang Pandangan Hidup Kyai, 1983, Jakarta: LP3ES. Hlm, 18.

${ }^{15}$ Nurcholis Madjid, Bilik-Bilik Pesantren Sebuah Potret Perjalanan, 1997, Jakarta: Paramadina. Hlm, 5.

16 Zamakhsyari Dhofier, Tradisi Pesantren...... Hlm, 44-55. 
antaranya adalah sebagai lembaga pendidikan dan keagamaan, tetapi juga sebagai lembaga pemberdayaan umat. Peran lainnya yaitu dapat memobilisasi masyarakat dalam perkembangan mereka, artinya lembaga ini dibangun atas dasar kepercayaan masyarakat bahwa pondok pesantren merupakan tempat yang tepat untuk menempa akhlak dan budi pekerti yang baik. Dalam sistem pendidikan yang dikembangkan oleh pondok pesantren sebagai upaya mengoptimalkan potensi yang dimiliki, pondok pesantren memberikan pelatihan khusus atau tugas magang dibeberapa tempat yang sesuai dengan pengembangan yang akan dilakukan di pondok pesantren.

Pesantren dikatakan sebagai lembaga pendidikan apabila termasuk dalam empat kelompok. Pertama yang merupakan bagian terbesar, yaitu kelompok pesantren yang tidak menyadari dirinya, apakah bernilai baik atau kurang baik, mereka menganggap bahwa apa yang terjadi adalah terjadi begitu saja tanpa ada persoalan serius yang perlu dipikirkan. Kedua yaitu fanatik karena dengan kefanatikan tersebut sering membuat penilaian yang kurang obyektif. Ketiga adalah kelompok yang dihinggapi rasa rendah diri, sehingga mereka merasa menganggap identitas pesantrennya tidak perlu lagi dipertahankan. Keempat yaitu pesantren-pesantren yang sepenuhnya menyadari bahwa dirinya baik dari segi-segi positif maupun negatif. Pondok tersebut dapat melihat dengan jernih mana yang harus diteruskan dan mana yang harus ditinggalkan. ${ }^{17}$

Keberagamaan dan juga perilaku beragama tidak hanya menjadi bagian dari sistem kesadaran, tetapi juga menjadi bagian integral di dalam sistem sosial. Cakupan lingkup keberagamaan dalam Islam yang demikian utuh, telah mencakup seluruh segi kehidupan manusia, dan disebabkan olehpengaruh lingkungan yang sangat beragam. Perilaku keberagamaan seseorang tersebut memerlukan akurasi sosok dimensi yang konkret. ${ }^{18}$

Perilaku keberagamaan seseorang dapat pula dinilai dari berbagai aspek, diantaranya yaitu aspek ibadah atau ritual keberagamaannya. Ibadah

${ }_{17}$ Nurcholis Madjid, Bilik-Bilik .....Hlm, 104-105.

18 Muslim Kadir A., Ilmu Islam Terapan Menggagas Paradigma Amali dalam Agama Islam, 2003, Yogyakarta: Pustaka Pelajar. Hlm, 278. 
dalam Islam sangat bermacam-macam bentuknya, maka dari itu islam membagi jenis-jenis pelaksanaan ibadah, seperti ibadah harian yang meliputi sembahyang lima waktu yang dalam Qs. al-Ankabut: 45 dinyatakan mempunyai fungsi dapat mencegah perbuatan mungkar. ${ }^{19}$

Dalam menjalankan aktivitas-aktivitas agama, biasanya santri sangat dipengaruhi oeh teman-temannya. Santri yang sering menarik diri dari masyarakat dan acuh tak acuh kepada agama biasanya disebabkan karena perlakuan dan sikap masyarakat yang kurang memberikan kedudukan yang jelas seringkali mempertajam konflik yang ada pada diri santri. Sehingga timbul kelompok-kelompok yang sikap dan tindakannya menentang nilainilai yang dianut masyarakat dan tak jarang yang menjadi sasaran adalah agama dan lembaga keagamaan. Jika lembaga keagamaan dapat memberi penghargaan dan menolong menyelesaikan masalah yang dihadapi santri, maka santri akan ikut aktif dan bekerja giat di bidang agama.

Perilaku keberagamaan akan melahirkan berbagai kreasi budaya dengan nilai kepercayaan yang termuat di dalamnya (H Baharun, 2011). Sebagai unsur yang berpengaruh bagi manusia, agama dapat memberikan layanan psikologi yang dibutuhkannya. Sementara manusia disisi lain juga memberikan kontribusi yang signifikan dalam membentuk tatanan dalam masyarak Pembinaan moral terjadi melalui pengalaman-pengalaman dan kebiasaan, yang ditanamkan sejak kecil oleh orang tua yang dimulai dengan pembiasaan hidup sesuai dengan nilai-nilai moral, yang ditirunya dari orang tua dan mendapat latihan untuk itu. Dalam pembinaan moral agama mempunyai peranan yang penting, karena nilai-nilai moral datang dari agama tetapi tidak berubah-ubah oleh waktu dan tempat. Dengan itu dapat ditegaskan bahwa Tuhan bagi santri adalah keharusan moral. Tuhan lebih menonjol sebagai penolong moral daripada sandaran emosi.

Dalam menjalankan aktivitas-aktivitas agama, biasanya santri sangat dipengaruhi oeh teman-temannya. Santri yang sering menarik diri dari masyarakat dan acuh tak acuh kepada agama biasanya disebabkan karena

${ }^{19}$ Abu Yasid, Islam Akomodatif, 2004, Yogyakarta: LkiS. Hlm, 45. 
perlakuan dan sikap masyarakat yang kurang memberikan kedudukan yang jelas seringkali mempertajam konflik yang ada pada diri santri. Sehingga timbul kelompok-kelompok yang sikap dan tindakannya menentang nilainilai yang dianut masyarakat dan tak jarang yang menjadi sasaran adalah agama dan lembaga keagamaan. Jika lembaga keagamaan dapat memberi penghargaan dan menolong menyelesaikan masalah yang dihadapi santri, maka santri akan ikut aktif dan bekerja giat di bidang agama.

Keberadaan (eksistensi) pesantren beserta perangkatnya sebagai lembaga pendidikan dan dakwah serta lembaga kemasyarakatan yang telah memberikan warna di daerah-daerah serta tumbuh dan berkembang bersama mayarakatnya sejak berabad-abad. Oleh karena itu tidak hanya secara kultural lembaga ini bisa diterima, bahkan telah ikut serta memberikan corak nilai kehidupan masyarakat yang senantiasa tumbuh dan berkembang. Latar belakang pesantren yang paling patut diperhatikan adalah peranannya sebagai alat transformasi kultural yang menyeluruh dalam masyarakat. ${ }^{20}$

Perkembangan teknologi dan ilmu pengetahuan yang sangat pesat mengalahkan segalanya. Kebanyakan anak-anak usia santri sering banyak menghabiskan waktunya untuk berlama-lama dengan bersosial media yang tak jarang mereka sering mengabaikan praktik keberagamaannya seperti sembahyang berjamaah, dan mengikuti kegiatan yang dapat meningkatkan spiritualitasnya.

Pondok pesantren merupakan salah satu solusi dalam menghadapi masalah kontemporer yang dihadapi oleh masyarakat muslim masa kini. Oleh karena itu, diperlukan pengelolaan pesantren yang tepat guna (Baharun, 2016a). Masalah yang tengah berkembang saat ini, terlebih mengenai perilaku keberagamaan santri sudah dapat dicarikan solusinya bersama-sama dengan cara dikembalikan pada syari'at hukum yang hakiki yaitu al-Qur'an dan Hadits.

Dalam meningkatkan perilaku keberagamaan santri, pondok pesantren yang berkembang saat ini mempunyai beberapa upaya dan langkah-langkah

\footnotetext{
${ }^{20}$ Zamakhsyari Dhofier, Tradisi Pesantren...... Hlm, 16.
} 
yang konkret selain menggunakan al-Qur'an dan Sunnah sebagai sumber dalam menghadapi berbagai persoalan yang ada. Berbagai metode dan cara belajar juga telah dikembangkan dari masa ke masa. Bahkan pondok pesantren modern saat ini telah memanfaatkan berbagai macam teknologi yang sedang berkembang di masyarakat sebagai sarana dakwah dan menarik perhatian pemuda muslim untuk tetap mempelajari ilmu agama. Dengan demikian, teknologi tidak dijadikan kambing hitam merosotnya moral keberagamaan santri manakala terdapat seorang yang mengarahkannya ke hal-hal yang positif. Selain memanfaatkan teknologi yang ada, pondok pesantren masa kini lebih banyak memberikan pelajaran yang bersifat empiris. Tujuannnya, setelah mereka keluar dari lingkungan pondok pesantren, dan terjun di lingkungan masyarakat mereka telah mempunyai bekal yang cukup.

\section{Program Pembinaan Pondok Pesantren}

Kegiatan yang sudah biasa dilakukan yaitu peringatan hari besar Islam di Nurul Jadid yang diisi dengan pengajian misalnya pada peringatan Hari Lahir (Harlah) Pondok Pesantren Nurul Jadid, Isra' Mi'raj, Halal bi Halal, Maulid Nabi Muhammad SAW, Tahun Baru Hijriyah dan sebagainya. Pondok pesantren Nurul Jadid juga menyelenggarakan kegiatan yang sama dengan bekerjasama dan melibatkan masyarakat sekitar khususnya santri sebagai pelaksana acara. Dengan diadakannya peringatan hari besar Islam tersebut, diharapkan intensitas pertemuan antara santri pondok pesantren dengan santri sekitar semakin bertambah. Sehingga tetap terjalin komunikasi yang baik antara kedua belah pihak. Melalui kegiatan-kegiatan yang beragam seperti contoh tersebut, secara tidak langsung pembinaan keberagamaan santri di Nurul Jadid dapat berjalan dengan baik.

Bentuk kegiatan lain yang dapat melibatkan peran serta santri di sekitar pondok pesantren Nurul Jadid adalah dengan didirikannya lembaga pendidikan non formal dan formal yang meliputi Madrasah Diniyah (non formal), Madrasah Ibtidaiyah, Madrasah Tsanawiyah, Madrasah Aliyah, SMP, SMA, SMK, dan Universitas merupakan salah satu bentuk pelayanan yang 
disediakan pondok pesantren Nurul Jadid bagi masyarakat secara luas, lebihlebih masyarakat sekitar. Mereka yang mempunyai anak usia sekolah dapat menitipkan anaknya untuk belajar mengenai Islam di semua lembaga tersebut. Dari sini dapat disimpulkan bahwa program pembinaan yang diadakan oleh pondok pesantren Nurul Jadid terhadap keberagamaan santri dapat berjalan maksimal. Hal ini dikarenakan berbagai faktor baik dari internal (manajemen pesantren) maupun eksternal (lingkungan masyarakat) yang saling memberikan dukungan.

\section{E. Pembinaan Keberagamaan dalam Pesantren}

Berdasarkan pengamatan yang penulis lakukan di lapangan dan teori pada bagian sebelumnya, maka peran Pondok Pesantren Nurul Jadid adalah sebagai fasilitator (Warliah, 2017). Keberadaan Pondok Pesantren Nurul Jadid dapat dijadikan sebagai sarana untuk menambah pengalaman keagamaan dan ilmu pengetahuan masyarakat sekitar. Dalam hal ini Pondok Pesantren Nurul Jadid sudah berupaya memberikan fasilitas dan pelayanan terbaik bagi terpenuhinya kebutuhan keberagamaan santri. Berbagai kegiatan yang diagendakan pondok pesantren tidak lain bertujuan untuk memberikan pembinaan kepada santri dan masyarakat. Ada beberapa kegiatan yang diperuntukkan bagi masyarakat khususnya santri sekitar pondok pesantren. Kegiatan tersebut umumnya dilakukan dalam rangka membina budi pekerti dan perilaku keberagamaan santri. Dengan melibatkan masyarakat khususnya santri di sekitar pondok pesantren dalam bidang pendidikan dan keagamaan, diharapkan mampu menambah pengalaman keberagamaan masyarakat. Sehingga perjalanan keberagamaan masyarakat didasarkan pada ilmu yang telah dikajinya. Peranan pondok pesantren berikutnya yaitu sebagai agent of development .

Keberadaan Pondok Pesantren Nurul Jadid diharapkan dapat dijadikan sebagai kontrol sosial keberagamaan masyarakat. Kebiasaan pondok pesantren yang melibatkan santri sekitar dalam beberapa kegiatan peringatan hari besar agama, menciptakan suasana akrab bagi santri dan masyarakat sehingga sesekali waktu mereka akan saling memberikan informasi yang 
positif. Pondok pesantren sebagai agent of excellence bukan hanya berperan sebagai tempat untuk transfer ilmu agama tetapi juga ilmu pengetahuan umum. Sehingga Pondok Pesantren Nurul Jadid berupaya menambahkan berbagai model pendidikan.

Kesadaran yang mulai tumbuh mengenai pesantren sering kali dengan memberikan penilaian bahwa sistem dalam pondok pesantren merupakan sesuatu yang bersifat asli. Hal ini dengan sendirinya bernilai positif dan harus dikembangkan. Penilaian tersebut menempatkan dunia pesantren pada pengakuan yang mempunyai peranan dalam pertumbuhan dan perkembangan pendidikan nasional. akan tetapi dalam sistem pendidikan nasional dinilai belum mampu menandingi organisasi-organisasi pendidikan lainnya.

\section{F. Simpulan}

Berdasarkan hasil penelitian yang telah dilakukan, maka peneliti dapat mengambil simpulan bahwa keberagamaan santri sekitar pondok pesantren dipengaruhi oleh kehidupan ekonomi masyarakat yang sebagian besar menengah ke bawah. Tokoh masyarakat setempat tidak dapat menuntut banyak tentang religiusitas santrinya, mereka berprinsip yang terpenting santri masih bisa dikendalikan dengan kegiatan-kegiatan yang positif karena berdampingan dengan lingkungan pondok pesantren.

Peran pondok pesantren dalam meningkatkan perilaku keberagamaan santri adalah sebagai fasilitator. Keberadaan pondok pesantren sedikit banyak memberikan peran bagi masyarakat khususnya para santri sekitar Pondok Pesantren Nurul Jadid. Sebagian santri telah memanfaatkan sarana yang disediakan sebagai tempat mengembangkan ilmu agama dan bertukar informasi kepada santri. Sehingga diharapkan program pembinaan berjalan secara maksimal. Kegiatan yang diadakan oleh pondok pesantren Nurul Jadid belum menyentuh semua lapisan masyarakat. Tetapi pondok pesantren telah berupaya memberikan pembinaan santri melalui TPA. Kurangnya kesadaran dan komunikasi antara masyarakat (khususnya santri) dengan pondok pesantren Nurul Jadid menjadikan terputusnya informasi keberagamaan yang 
akan disampaikan. Hal tersebut berimbas pada kualitas sumber daya manusia santri sekitar pondok pesantren Nurul Jadid.

Pondok pesantren Nurul Jadid secara tidak langsung menjalankan perannya sebagai agent of development atau kontrol sosial. Meskipun kurang berjalan secara maksimal, namun pondok pesantren bersama-sama masyarakat berupaya mengutamakan perkembangan akhlak santri. Peran lainnya yaitu sebagai agent of excellence. Masyarakat sekitar pondok pesantren kurang tertarik dengan kegiatan yang dilakukan pondok pesantren Nurul Jadid. Mereka beralasan kegiatan yang diadakan kurang variatif. Meskipun demikian pondok pesantren Nurul Jadid berupaya memberikan sarana dan pelayanan bagi masyarakat yang ingin memperdalam ilmu agamanya.

Relasi Pondok Pesantren Nurul Jadid dengan masyarakat sekitar pondok pesantren terjalin secara individu maupun personal antara Pondok Pesantren Nurul Jadid dengan masyarakat tidak ada masalah yang berarti. Mereka sedapat mungkin menjalin komunikasi yang baik. Dalam hubungan kelembagaan, santri sering disertakan dalam berbagai kegiatan yang diagendakan pondok pesantren. Hal ini menunjukkan adanya komunikasi yang baik terjalin antara lembaga Pondok Pesantren Nurul Jadid dengan masyarakat sekitar terutama kalangan santri. Bukan hanya Pondok Pesantren Nurul Jadid saja yang berupaya membangun komunikasi dengan masyarakat, melainkan juga dari pihak masyarakat. Masyarakat di sekitar pondok pesantren mengakui keberadaan santri pondok dan menganggap mereka merupakan bagian dari masyarakat.

Pembinaan yang dilakukan Pondok Pesantren Nurul Jadid terhadap keberagamaan santri secara langsung yang dilakukan oleh pondok pesantren tidak ada, namun ada berbagai program yang diadakan pondok pesantren dan secara tidak langsung memberikan pembinaan terhadap keberagamaan santri sekitar di antaranya mengadakan peringatan Hari Lahir (Harlah) Pondok Pesantren Nurul Jadid, Isra' Mi'raj, Halal bi Halal, Maulid Nabi Muhammad SAW, Tahun Baru Hijriyah dan sebagainya. 


\section{DAFTAR PUSTAKA}

Baharun, H. (2017). Pengembangan Kurikulum; Teori dan Praktik (Konsep, Prinsip, Pendekatan dan Langkah-langkah Pengembangan Kurikulum PAI. Yogyakarta: CV Cantrik Pustaka.

Baharun, H. (2016a). Management Of Quality Education In Pesantren: The study of the Education Quality Improvement Pesantren by Strategy Management Approach. (2nd INTERNATIONAL CONFERENCES ON EDUCATION AND TRAINING (ICET), Ed.). Malang: UM Malang.

Baharun, H. (2016b). PENDIDIKAN ANAK DALAM KELUARGA; TELAAH EPISTEMOLOGIS. Pedagogik, 3(2), 96-107.

Baharun, H. (2017). Total Moral Quality: A New Approach for Character Education in Pesantren. Ulumuna, 21(1), 57-80.

Darajat, Zakiyah, Pembinaan Santri, 1976, Jakarta: PT. Bulan Bintang.

---------, Problematika Santri di Indonesia, 1978, Jakarta: PT. Bulan Bintang.

---------, Peran Agama dalam Kesehatan Mental, 1994, Jakarta: CV. Haji Masagung.

---------, Ilmu Jiwa Agama, 1996, Jakarta: PT. Bulan Bintang.

Depdiknas, Kamus Besar Bahasa Indonesia Edisi ketiga, 2007, Jakarta: Balai Pustaka.

Dhofier, Zamakhsyari, Tradisi Pesantren: Studi tentang Pandangan Hidup Kyai, 1983, Jakarta: LP3ES.

Fauzi, Muhammad, Agama dan Realitas Sosial Renungan dan Jalan Menuju Kebahagiaan, 2007, Jakarta: PT Raja Grafindo Persada.

Galba, Sindu, Pesantren Sebagai Wadah Komunikasi, 1995, Jakarta: PT Rineka Cipta.

H Baharun, A. M. (2011). Metodologi Studi Islam: Percikan Pemikiran Tokoh Dalam Membumikan Agama. Jogjakarta: Ar-Ruzz Media.

Ishomuddin, Pengantar Sosiologi Agama, 2002, Jakarta: Ghalia Indonesia.

Kadir, Muslim. A, Ilmu Islam Terapan Menggagas Paradigma Amali dalam Agama Islam, 2003, Yogyakarta: Pustaka Pelajar.

Kasiram, Moh., Metodologi Penelitian Kualitatif-Kuantitatif, 2010, Yogyakarta: UINMaliki Press.

Madjid, Nurcholis, Bilik-Bilik Pesantren Sebuah Potret Perjalanan, 1997, Jakarta: Paramadina. 
Martin, Richard C., Pendekatan Kajian Islam dalam Studi Agama, 2001, Surakarta: Muhammadiyah University Press.

Moleong, Lexy. J., Metodologi Penelitian Kualitatif, 2009, Bandung: PT Santri Rosda Karya.

Mu'tasim, Rajasa, Perlawanan Santri Pinggiran, 2010, Yogyakarta: PT. Bintang Pustaka Abadi.

Nafi', M. D., dkk., Praksis Pembelajaran Pesantren, 2007, Yogyakarta: Institute for Training and Development Amherst MA.

Nasution, Harun, Islam Ditinjau dari Beberapa Aspeknya, 1985, Jakarta: UI Press.

Sudarsono, Kenakalan Santri, 2004, Jakarta: Rineka Cipta.

Sugiyono, Metode Penelitian Kuantitatif dan Kualitatif dan RED, 2011, Bandung: Alfabeta.

Suprayogo, Imam dan Tobroni, Metodologi Penelitian Sosial Agama, 2001, Bandung: PT Santri Rosdakarya.

Sriyanti, Lilik, dkk., Teori-Teori Belajar, 2011, Salatiga: STAIN Salatiga.

Yasid, Abu, Islam Akomodatif, 2004, Yogyakarta: LkiS.

Warliah, W. (2017). PENDIDIKAN BERBASIS GENDER AWARENESS; STRATEGI MEMINIMALISIR BIAS GENDER DI PONDOK PESANTREN. JURNAL ISLAM NUSANTARA, 1(2). 